\title{
Development of an Aggregate Air Quality Index Using a PCA-Based Method: A Case Study of the US Transportation Sector
}

\author{
Jaesung Choi, Yong Shin Park, Ju Dong Park* \\ Upper Great Plains Transportation Institute, North Dakota State University, Fargo, ND, USA \\ Email: "judong.park@ndsu.edu
}

Received 23 January 2015; accepted 9 February 2015; published 15 February 2015

Copyright (C) 2015 by authors and Scientific Research Publishing Inc.

This work is licensed under the Creative Commons Attribution International License (CC BY). http://creativecommons.org/licenses/by/4.0/

(c) () Open Access

\section{Abstract}

For the past couple of decades, the transportation sector has made efforts to preserve and improve air quality for public health and sustainable growth between current and future generations. An easily understandable tool to measure the level of air pollution in the transportation sector by considering multiple air pollutants together might raise awareness about clean air to the public, practitioners, state policy planners, and the government. For this reason, this study develops an aggregate air quality index to help prepare decision makers, which could rank a state according to the different levels of multiple air pollutants. The index is developed for use with principal component analysis and an algebra about a line segment, and then applied to the US transportation sector using data on five air pollutants (CO, NOx, $\mathrm{PM}, \mathrm{SO}_{2}$, and VOCs) in 2008 . This study finds that some states were less polluted or more polluted in terms of the index, although their GDP levels for a transport mode were similar to each other. Thus, this finding implies that the necessary actions for stricter air quality standards must be taken in their boundaries.

\section{Keywords}

Aggregate Air Quality Index, Air Pollution, Multivariate Analysis, Principal Component Analysis (PCA), Sustainable Growth, Transportation Sector

\section{Introduction}

Transport modes emit air pollutants such as carbon monoxide (CO), nitrogen oxides $\left(\mathrm{NO}_{\mathrm{x}}\right)$, particulate matter (PM), sulfur dioxide $\left(\mathrm{SO}_{2}\right)$, and volatile organic compounds (VOCs) into the air through fossil fuel combustion.

\footnotetext{
*Corresponding author.
}

How to cite this paper: Choi, J., Park, Y.S. and Park, J.D. (2015) Development of an Aggregate Air Quality Index Using a PCA-Based Method: A Case Study of the US Transportation Sector. American Journal of Industrial and Business Management, 5, 53-65. http://dx.doi.org/10.4236/ajibm.2015.52007 
Such air pollution frequently exposes human health to acute and chronic diseases, and in the short- and longterms might result in premature death and declines in life expectancy [1]. Further, it is reported by several researchers that outdoor air pollution negatively affects the productivity of indoor workers [2]-[7].

Transportation is essential for economic growth at the local and national levels, but it is highly connected to environmental pollution, especially air pollution [8]. Gorham's 2002 report [9] for the United Nations shows how much fossil fuel is being combusted by transportation: the transportation sector consumes 25 percent of total worldwide energy consumption and uses more than 50 percent of the total oil produced. Furthermore, annual demand for transport modes is projected to grow by 3.6 percent in developing countries and by 1.5 percent in developed countries [9]. Finally, it might be appropriate to recognize transportation's air pollution emissions as one of the most serious sources of ongoing atmospheric pollution in the world.

Daily air quality indices that evaluate the levels of air pollutants measured at monitoring stations have been developed by a number of researchers [10]-[22] to inform the public about how polluted their living areas are. However, the indices developed until now have a couple of limitations. First, mathematical models for developing air quality indices are based on daily air pollution data (to report daily levels of health concern to the public); this means that without any data measured per day, the model is useless. Second, air pollution data measured at monitoring stations generally represent the levels of overall air pollution in that area, and thus the model cannot be applied to any specific air emissions source, e.g., transportation, to suggest the degree of pollution by transport mode in a state or city.

Nonetheless, under the Clean Air Act ${ }^{1}$ the US Environmental Protection Agency (USEPA) has an obligation to provide national emissions inventory (NEI) data ${ }^{2}$. As a result, air pollution emissions data available to the public have been estimated by the USEPA in order to inform people and the authorities of an air pollutant concentration in an air emissions source every three years by state since 2002 .

By using air pollution data by transport mode (airline, rail, truck, and vessel) in $2008^{3}$, this study develops an aggregate air quality index (AAQI) using principal component analysis (PCA) to measure the relative levels of air quality by transport mode in a state in the US. The model developed and findings have the advantage of being useful as an administrative tool for making air pollution regulations in the transportation sector at state and national levels and providing the authorities and people with easily understandable information about the levels of air quality by transport mode in a state. The second section of this study presents a literature review on changes to the development of air quality indices and the third section presents the methodology about developing an AAQI. The fourth section is the data. After the results are presented, the conclusions discuss the developed AAQI and air pollution changes by state based on the index.

\section{Literature Review}

Thom and Ott [10] in 1975 started to develop a uniform air quality index (AQI) through a detailed survey of the air pollution indices in the US and Canada, since at that time states and cities in the US used different daily informational indices. Indeed, an index value in one state meant something entirely different in other states. However, following the Federal Interagency Task Force [11], a daily pollutant standards index (PSI) was developed to report daily air pollution levels to the public, because the index developed by Thom and Ott [10] was criticized as being poor and confusing. In 1998, Hämekoski [12] introduced a PSI developed by the Federal Interagency Task Force [11] to provide a simple AQI in order to inform the public of daily air quality in Finland.

The USEPA [13] in 1999 adopted some revisions for the uniform AQI, which incorporates new breakpoints for ozone and PM, and changed its name from the PSI to the AQI. The AQI consists of sub-indices calculated for each pollutant, with the maximum index then selected between different indices to represent the level of air quality. Following Trozzi et al. [14], Sharma et al. [15] [16], Murena [17], Nagendra et al. [18], Wen et al. [19], and Eder et al. [20], the AQI developed by the USEPA was used in several countries for reporting daily air quality. On the other hand, Swamee and Tyagi [21] applied an ambiguity- and eclipsicity-free function to develop an overall AQI from the aggregation of air pollution sub-indices.

The disadvantage of the AQI developed by the USEPA was that it only considered the levels of one pollutant at a time and thus the index could not identify if multiple air pollutants exceeded their daily air quality standards

\footnotetext{
${ }^{1}$ The Clean Air Act was enacted in 1963 and revised in 1970 and 1990 to establish national air quality standards in the US [37].

${ }^{2} \mathrm{NEI}$ is an estimate of air emissions from all air emissions sources from 2002 to 2011 every three years [42].

${ }^{3}$ The updated calculation methodology for data in 2008 was not consistent with 2002 and 2005, and air pollution data in 2011 were not available during the study period.
} 
[22]. To address this limitation, a couple of methodologies have been developed by several researchers [22]-[25] to include the combined effects of major air pollutants. On the other hand, Longhurst [26] developed a simplified mathematical formula to measure an AQI for $\mathrm{SO}_{2}$ and particulates, while a time series regression analysis by Stieb et al. [27] [28] has been developed to illustrate the relationship between five air pollutants and mortality. Recently, Mohan and Kandya [29] and Mayer et al. [30] analyzed the effect of long-term air pollution, while Sowlat et al. [31] developed a computation method of artificial intelligence to assess the performance of a fuzzy-based AQI.

Research using a PCA-based method have been noticed in recent years by several researchers [32]-[36] for developing composite sustainability indicators in a variety of fields. In 2006, Vyas and kumaranayake [32] tried to construct socio-economic status indices to measure household wealth, while Soler-Rovira [33] developed an environmental indicator for 36 countries for agricultural production in 2008. In 2009, Ali [34] suggested a practical way of developing Arab water sustainability index to promote more efficient water use within the Arab countries. On the other hand, Li et al. [35] constructed an overall sustainability performance indicator for the manufacturing industry to provide the industry and academia with an integrated methodology, and Hosseini and Kaneko [36] developed dynamic sustainability indicators at the macro level in 2011. Appendix A summarizes the literature on changes to the development of air quality indices.

\section{Methodology}

PCA is generally used for one sample without grouping among the observations, and the technique seeks to find the maximum of the variance of a linear combination of the variables [37]-[41]. The maximum of the variance of a linear combination of the variables is the first principal component, and the second principal component is perpendicular to the first principal component with the maximal variance of the linear combination of the variables. This process keeps going until it finds p principal components, where $p$ is the number of variables [40].

The principal components of the transformed variables are shown with the normalized eigenvectors $\boldsymbol{a}_{j}$ of the sample covariance matrix $\boldsymbol{S}$ of the sample of observation vectors $\boldsymbol{y}_{1}, \boldsymbol{y}_{2}, \cdots, \boldsymbol{y}_{n} \quad$ [40]:

$$
A=C^{\prime}=\left[\begin{array}{c}
a_{1}^{\prime} \\
a_{2}^{\prime} \\
\vdots \\
a_{p}^{\prime}
\end{array}\right]
$$

where $\boldsymbol{a}_{j}$ is the $\boldsymbol{j}^{\text {th }}$ normalized eigenvector of $\boldsymbol{S}$ and $\boldsymbol{C}$ is the orthogonal matrix consisting of $\boldsymbol{a}_{j}$,

$$
\mathbf{z}_{i}=\boldsymbol{A y}_{i}=\left[\begin{array}{c}
a_{11} y_{i 1}+a_{12} y_{i 2}+\cdots+a_{1 p} y_{i p} \\
a_{21} y_{i 1}+a_{22} y_{i 2}+\cdots+a_{2 p} y_{i p} \\
\vdots \\
a_{p 1} y_{i 1}+a_{p 2} y_{i 2}+\cdots+a_{p p} y_{i p}
\end{array}\right]=\left[\begin{array}{c}
z_{1 i} \\
z_{2 i} \\
\vdots \\
z_{p i}
\end{array}\right]
$$

According to Rencher and Christensen [40], the eigenvalues $\Lambda_{1}, \Lambda_{2}, \cdots, \Lambda_{p}$ are obtained from $S$, and $\Lambda_{1}$ is the biggest eigenvalue of $\boldsymbol{S}$. The first principal component $z_{1}$ shows the largest sample variance, whereas the variance of the last principal component $z_{p}$ is the smallest. Since the eigenvalues are equal to the variances of the principal components, the percentage of variance explained by the first $k$ principal components is as follows:

$$
\text { Percentage of variance }=\frac{\Lambda_{1}+\Lambda_{2}+\cdots+\Lambda_{k}}{\sum_{1}^{p} \Lambda_{j}}
$$

We only expect to substitute the variables $y_{1}, y_{2}, \cdots, y_{p}$ for the first principal component

$$
\left(z_{1}=a_{1} y_{1}+a_{2} y_{2}+\cdots+a_{p} y_{p}\right),
$$


which accounts for more than 80 percent of the total variance ${ }^{4}$ since the dependent variables of air pollutants emissions are highly correlated with each other [42]-[44]. If this case is established, then a concept of a line segment is introduced to develop an AAQI in the transportation sector: 1) list all measurements calculated from the first principal component on a line segment and then find the maximum and minimum measurements, which are the most polluted and the least polluted observations, respectively; 2) measure the length of the line segment between the maximum and minimum measurements; and 3) calculate a proportion for each measurement from the ratio of the length of the line segment between the minimum measurement and each measurement to the length measured in 2), and then multiply the calculated values by 100 . The least polluted observation indicates 0 , while the most polluted observation indicates 100 .

In Figure 1, this study illustrates a simple example to calculate an AAQI. Four measurements $Z_{11}, Z_{12}, Z_{13}$ and $Z_{14}$ are calculated from the first principal component representing the levels of multiple air pollutants. The length of the line segment for each measurement is as follows: $\overline{Z_{11} Z_{14}}=12 ; \overline{Z_{11} Z_{12}}=4$; and $\overline{Z_{11} Z_{13}}=8$. Therefore, the proportions of the four measurements are $0,0.333\left(\frac{4}{12}\right), 0.666\left(\frac{8}{12}\right)$, and 1 , respectively. The AAQIs for $Z_{11}, Z_{12}, Z_{13}$ and $Z_{14}$ finally are calculated as $0,33.3,66.6$, and 100 , respectively.

\section{Data}

An AAQI using PCA and the concept of a line segment was developed in Section 3 for multiple air pollutants. Under the Clean Air Act, the USEPA provides air quality standards for the five common air pollutants to suggest air quality guidelines to state policy planners and industrial sectors and protect public health [42]. For this reason, the five air pollutants of $\mathrm{CO}, \mathrm{NO}_{\mathrm{x}}, \mathrm{PM} \mathrm{SO}_{2}$, and VOCs were used for the index. Since principal components are not scale-invariant, all variables should be measured in the same units [3]; therefore, all variables measured in tons were utilized by each transport mode in the 53 states in the US These were obtained from the NEI of the USEPA in 2008, and were the latest estimated air pollutants available during the study period [48].

Table 1 shows the summary statistics for the data utilized in this study. The five air pollutants measured for each transport mode by state do not show any kind of heterogeneity since the coefficient of variation in each variable calculated was less than 10 [45]. For the airline transport mode, Texas emits the largest air pollution for each air pollutant, while District of Columbia shows the least air pollution. On the other hand, Idaho emits the fewest air pollutants for vessel and Louisiana shows the largest air pollution in $\mathrm{CO}, \mathrm{NO}_{\mathrm{x}}, \mathrm{PM}$, and VOCs, but Texas is the largest $\mathrm{SO}_{2}$ emission state. For rail, Nebraska contributes to the largest air pollution across the nation for the four air pollutants, but Texas emits the largest $\mathrm{SO}_{2}$ emission as in the vessel case. For all five air pollutants, Rhode Island emits the least air pollution. For truck, California is the number one air pollution-emitting state for $\mathrm{CO}, \mathrm{NO}_{\mathrm{x}}$, and VOCs, while Texas is for $\mathrm{PM}$ and $\mathrm{SO}_{2}$. The least air pollution state for $\mathrm{NO}_{\mathrm{x}}$, $\mathrm{PM}$, and $\mathrm{SO}_{2}$ is Idaho, but that for CO and VOCs is Rhode Island.

Figure 2 provides a geographic map showing the study area where the five air pollutants were emitted. The NEI provides them by state, but there are no data available for some states for the vessel, rail, and truck transport sectors: Arizona, Colorado, Montana, North Dakota, New Mexico, Nevada, South Dakota, Utah, Virgin Islands, Vermont, and Wyoming in vessel; and Hawaii, Puerto Rico, and Virgin Islands in rail and truck.

\section{Empirical Results}

Like most multivariate analyses where the data used follow the multivariate normal (or at least approximately multivariate normal) distribution [46], this study uses a multivariate analysis with PCA. Thus, the developed AAQI tests two statistical assumptions. The first assumption is of multivariate normality. In Figure 3, the scatter plot matrix on the left indicates that the original data do not suggest any normality and even each variable shows

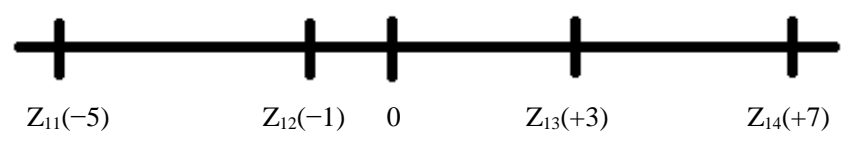

Figure 1. Line segment to calculate an AAQI of the example.

${ }^{4}$ Deciding on the number of components followed a recommendation of retaining sufficient components to account for at least 80 percent of the total variance [40]. 
Table 1. Summary statistics for the five air pollutants emitted by the four transport modes.

\begin{tabular}{|c|c|c|c|c|c|c|}
\hline \multicolumn{7}{|c|}{ Airline } \\
\hline Pollutant & N. of Obs. & Mean & Std. Dev. & Min. & Max. & CV \\
\hline CO (tons) & 53 & 8268.350 & 9963.030 & 11.979 & 54029.810 & 1.205 \\
\hline $\mathrm{NO}_{\mathrm{X}}$ (tons) & 53 & 2277.850 & 3401.790 & 0.266 & 17043.920 & 1.493 \\
\hline PM (tons) & 53 & 180.919 & 211.983 & 0.272 & 1145.140 & 1.172 \\
\hline $\mathrm{SO}_{2}$ (tons) & 53 & 239.642 & 351.130 & 0.058 & 1866.450 & 1.465 \\
\hline VOCs (tons) & 53 & 625.677 & 1018.070 & 0.465 & 6144.000 & 1.627 \\
\hline \multicolumn{7}{|c|}{ Vessel } \\
\hline Pollutant & N. of Obs. & Mean & Std. Dev. & Min. & Max. & CV \\
\hline CO (tons) & 42 & 2065.370 & 4053.190 & 0.005 & 23719.810 & 1.962 \\
\hline $\mathrm{NO}_{\mathrm{X}}$ (tons) & 42 & 12771.610 & 23159.440 & 0.027 & 132292.350 & 1.813 \\
\hline PM (tons) & 42 & 645.534 & 1074.950 & 0.001 & 5677.870 & 1.665 \\
\hline $\mathrm{SO}_{2}$ (tons) & 42 & 3403.410 & 5582.650 & 0.002 & 23870.760 & 1.640 \\
\hline VOCs (tons) & 42 & 342.995 & 564.392 & 0.001 & 3110.910 & 1.645 \\
\hline \multicolumn{7}{|c|}{ Rail } \\
\hline Pollutant & N. of Obs. & Mean & Std. Dev. & Min. & Max. & $\mathrm{CV}$ \\
\hline CO (tons) & 50 & 2398.720 & 2082.860 & 8.592 & 10858.510 & 0.868 \\
\hline $\mathrm{NO}_{\mathrm{X}}$ (tons) & 50 & 16913.600 & 14342.040 & 87.267 & 74404.650 & 0.848 \\
\hline PM (tons) & 50 & 551.335 & 476.072 & 2.148 & 2484.400 & 0.863 \\
\hline $\mathrm{SO}_{2}$ (tons) & 50 & 215.729 & 273.284 & 0.607 & 1736.870 & 1.267 \\
\hline VOCs (tons) & 50 & 883.754 & 763.524 & 3.222 & 3760.480 & 0.864 \\
\hline \multicolumn{7}{|c|}{ Truck } \\
\hline Pollutant & N. of Obs. & Mean & Std. Dev. & Min. & Max. & CV \\
\hline CO (tons) & 50 & 18677.270 & 20442.930 & 918.432 & 99166.890 & 1.095 \\
\hline $\mathrm{NO}_{\mathrm{X}}$ (tons) & 50 & 63501.130 & 69821.420 & 2577.990 & 363276.210 & 1.100 \\
\hline PM (tons) & 50 & 3524.960 & 3706.050 & 159.779 & 18699.870 & 1.051 \\
\hline $\mathrm{SO}_{2}$ (tons) & 50 & 92.377 & 92.783 & 3.666 & 467.146 & 1.004 \\
\hline VOCs (tons) & 50 & 4214.540 & 4634.510 & 225.378 & 24122.660 & 1.100 \\
\hline
\end{tabular}

Note: All air pollutants data come from the NEI in the USEPA [48].

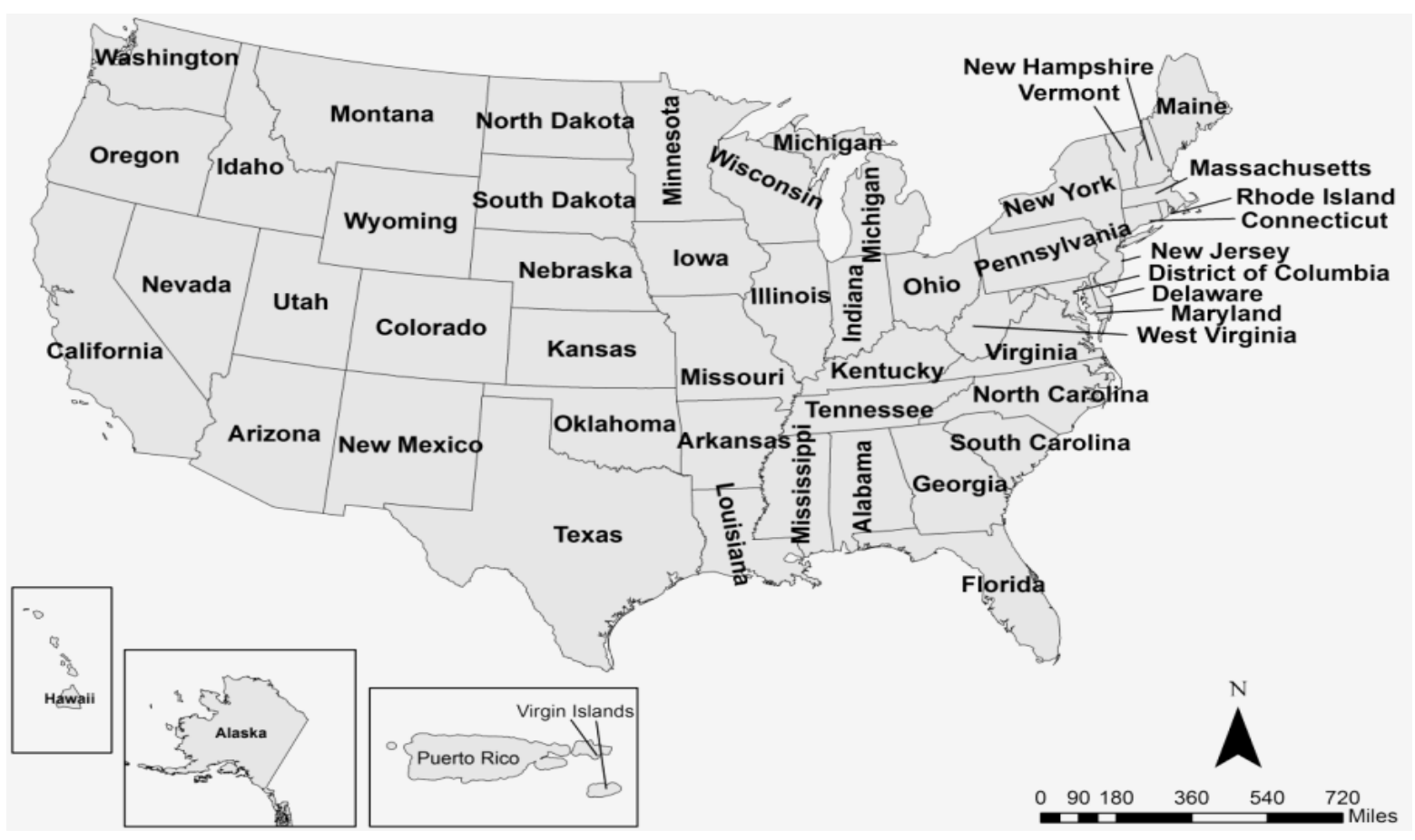

Figure 2. Geographic map showing the study area where the five air pollutants were emitted. 
a positive skew. On the other hand, after the transformation of the original data ${ }^{5}$, the right side in Figure 3 shows the approximate normal distribution for each variable. The Q-Q plot for each variable does not show any distinct nonlinear relationship, not indicating a departure from the multivariate normality distribution [40].

The second assumption is that this study can only use one principal component to sufficiently represent the five air pollutants $y_{1}, y_{2}, y_{3}, y_{4}, y_{5}$. To check this, the scree plots and proportion of variance explained by each principal component were tested (see Figure 4). The scree plots in all the transport modes reveal an evident natural break between the first and second principal components. Further, the proportion of the first principal component calculated ${ }^{6}$ shows more than 90 percent in each transport, which is much higher than a recommendation of retaining enough components to account for 80 percent of the total variance [40]. Being able to use only a first principal component to explain most of the total variance provides a significantly practical and convenient tool to interpret multiple air pollutants. For example, in the original data in 2008 by airline transport, two states, Iowa and Idaho, emitted the five air pollutants of $\mathrm{CO}, \mathrm{NO}_{\mathrm{x}}, \mathrm{PM}, \mathrm{SO}_{2}$, and VOCs as follows: 2679, 272, 59, 37, and 119 (tons) and 3975, 255, 91, 35, and 147 (tons), respectively. In terms of individual air pollutants, Idaho emitted more (less) air pollution in $\mathrm{CO}, \mathrm{PM}$, and VOCs $\left(\mathrm{NO}_{\mathrm{x}}\right.$ and $\left.\mathrm{SO}_{2}\right)$ than Iowa, but practitioners, state policy planners, and the public might want to know the overall air quality level from this kind of conservative situation. The first principal component calculated from the normalized eigenvectors of the sample covariance matrix was used to address this problem.

By using PCA and a little bit of algebra about a line segment with the transformed data, the first principal component and the AAQI by state in the airline, vessel, rail, and truck transport sectors were calculated, as shown in Table 2 and Table 3. In addition, to compare the relative levels of air quality by state from the indices, the state GDP in each transport mode was added in these tables. Each state is ranked relative to all other observed values of states in the first principal component, from smallest to largest in order of magnitude. The rank of each state is denoted by its AAQI. The index increases from 0 to 100, and this indicates more air pollution when it approaches a higher index value. The index of a state showing 100 means the largest air pollution-emitting state of all. On the other hand, a state index indicating 0 implies that the state is the least air pollution-emitting state.

(A) Scatter plot matrix before the transformation

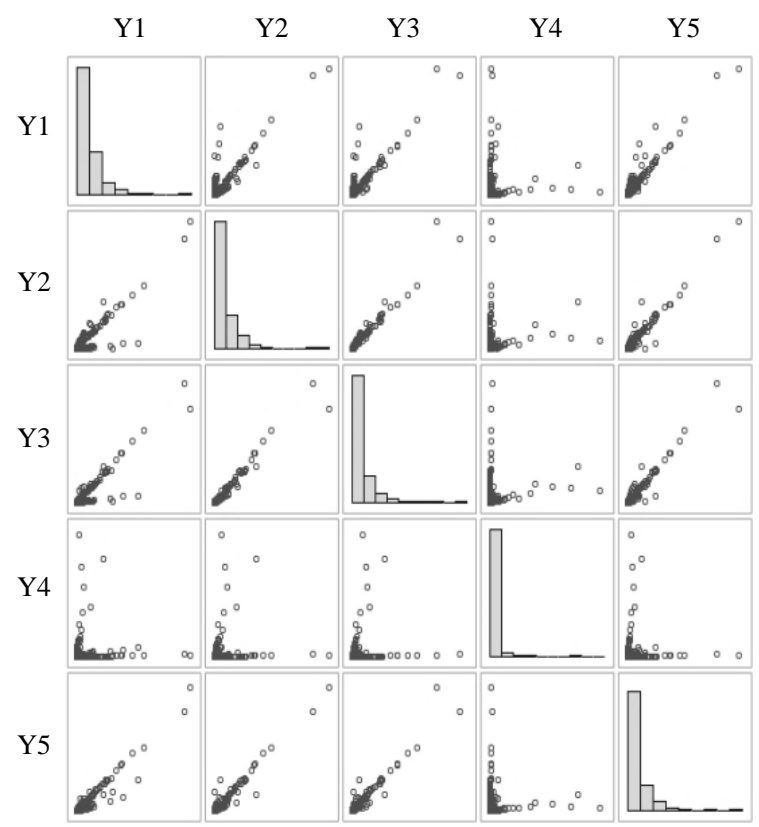

(B) Scatter plot matrix after the transformation

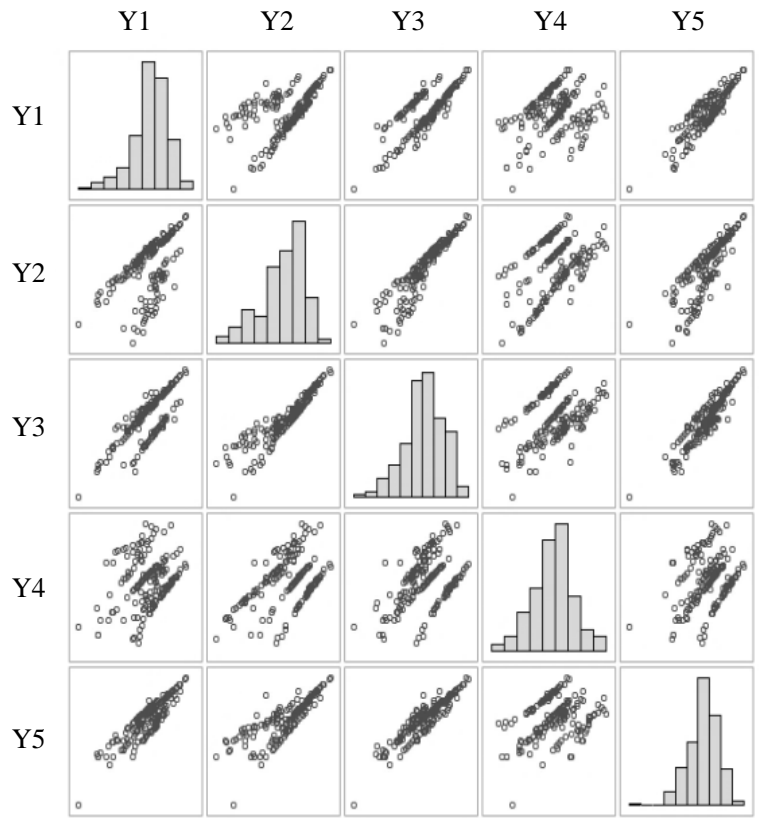

Figure 3. Tests for departures from multivariate normality in the data set before and after the transformation.

${ }^{5}$ In an attempt to make the individual variables distributed more closely to a normal distribution and them distributed more closely to a multivariate normal distribution, the following variables were used in this study: $y_{1}^{*}=\sqrt[2]{\ln y_{1}} ; \quad y_{2}^{*}=\sqrt[2]{\ln y_{2}} ; \quad y_{3}^{*}=\sqrt[2]{\ln y_{3}} ; \quad y_{4}^{*}=\sqrt[2]{\ln y_{4}} ;$ and $y_{5}^{*}=\sqrt[2]{\ln y_{5}}$.

${ }^{6}$ The first principal component in airline: 93.4 percent; in vessel: 95 percent; in rail: 97.8 percent; and in truck: 97.3 percent. 

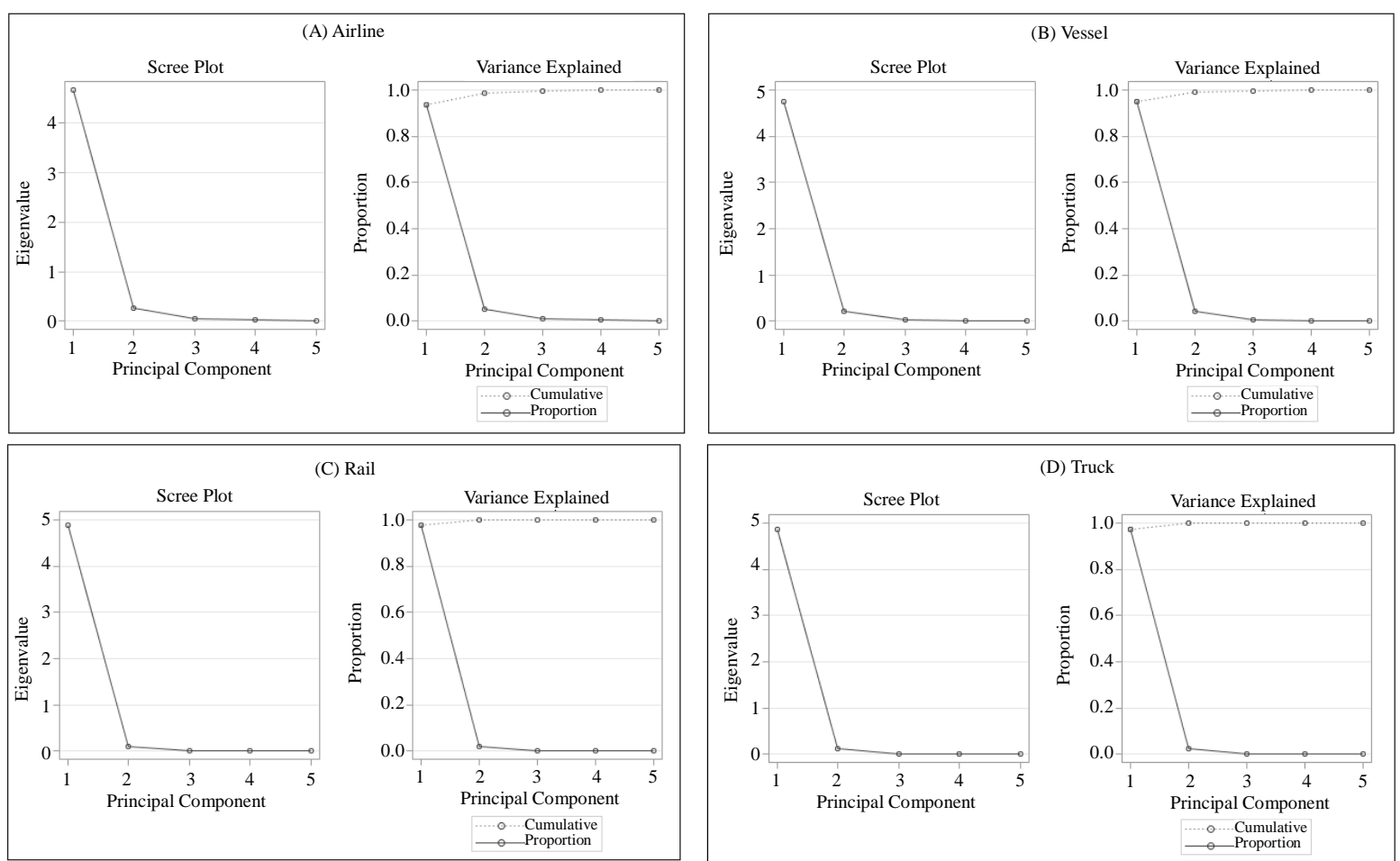

Figure 4. The eigenvalues and proportion of variance explained by the first k principal components by each transport mode $(k=1,2,3,4,5)$.

The AAQIs in Table 2 and Table 3 are on the ordinal scale; in other words, it is only possible to distinguish each state on the basis of the relative amounts of multiple air pollutants. For instance, in vessel transport in Table 2, the index of Iowa shows 34.01, while that of Kentucky is 70.55. This does not tell us whether the air pollution by vessel in Kentucky is twice more polluted than that in Iowa, but rather it is interpretable in the way that Kentucky shows worse air pollution in terms of considering multiple air pollutants than Iowa. In fact, in 2008 Iowa emitted 151, 786, 27, 46, and 17 (tons) of CO, $\mathrm{NO}_{\mathrm{x}}, \mathrm{PM}, \mathrm{SO}_{2}$, and VOCs, respectively, whereas Kentucky emitted a considerable amount of air pollutants: 1847, 11370, 441, 594, and 300 (tons).

In Table 2, the vessel and rail transport sectors are first analyzed. In vessel transport, Oklahoma is the least air pollution-emitting state, but Louisiana shows the largest air pollution. Indiana, Illinois, Missouri, North Carolina, West Virginia, and Tennessee account for a relatively low AAQI compared with their high GDP levels, whereas Alaska, Michigan, Wisconsin, and Washington hold high ranks in the AAQI compared with their low GDP levels. For rail transport, Delaware takes the lowest rank in the index and Nebraska accounts for the highest rank. Florida, Georgia, and Texas show relatively low air pollution against their high GDP level. Massachusetts, Maryland, Missouri, Oregon, and Pennsylvania in vessel transport, consisting of a similar GDP scale, are differently ranked in the AQI, and this happens to rail transport with Arizona, Colorado, Florida, Montana, Tennessee, and Washington.

In Table 3, as this study expected based on the original data for the airline transport sector, where Texas was the largest air pollution-emitting state with respect to the five air pollutants, the Texas AAQI now reaches the highest. By contrast, Delaware holds the lowest rank in the AAQI. Connecticut, Minnesota, and New Jersey emit relatively low air pollution compared with their high GDP levels, while Alabama, Alaska, Massachusetts, Mississippi, Tennessee, and Wisconsin hold high ranks in the AAQI against their relatively low GDP levels. In truck transport, Idaho is ranked the least air pollution-emitting state, which even shows a relatively high GDP level. Truck transport was a little conservative to choosing the largest air polluting state with multiple air pollutants in the original data between Texas and California, but California is chosen as the largest air pollutionemitting state and Texas is ranked right behind it. Florida, Georgia, Michigan, New Mexico, and North Carolina, showing relatively low GDP levels, hold a high rank in the AAQI, whereas Arkansas, Iowa, Nevada, Nebraska, North Dakota, and South Dakota are ranked low in the index compared with their high GDP levels. In airline, 
Table 2. The first principal component and AAQI by state in the vessel and rail transport sectors.

\begin{tabular}{|c|c|c|c|c|c|c|c|}
\hline \multicolumn{4}{|c|}{ Vessel } & \multicolumn{4}{|c|}{ Rail } \\
\hline State & GDP & PC1 & AAQI & State & GDP & PC1 & AAQI \\
\hline Oklahoma & 1 & -7.60 & 0 & Delaware & 86 & -5.85 & 0 \\
\hline Iowa & 31 & -3.66 & 34.01 & Vermont & 17 & -5.50 & 3.96 \\
\hline New Hampshire & 3 & -3.21 & 37.80 & District of Columbia & 107 & -5.22 & 7.03 \\
\hline Rhode Island & 19 & -2.37 & 45.10 & New Hampshire & 8 & -4.85 & 11.16 \\
\hline Arkansas & 17 & -2.16 & 46.84 & Maine & 47 & -4.00 & 20.66 \\
\hline Indiana* & 291 & -1.89 & 49.23 & Connecticut & 40 & -3.45 & 26.84 \\
\hline Tennessee $^{*}$ & 335 & -1.66 & 51.21 & Alaska & 0 & -3.44 & 26.89 \\
\hline Missouri $^{* \circ}$ & 165 & -1.41 & 53.31 & New Jersey & 171 & -2.98 & 32.04 \\
\hline West Virginia $^{*}$ & 110 & -1.04 & 56.52 & South Dakota & 159 & -1.59 & 47.56 \\
\hline South Carolina & 37 & -1.04 & 56.57 & Maryland & 242 & -0.89 & 55.44 \\
\hline Georgia & 45 & -0.98 & 57.01 & Massachusetts & 263 & -0.88 & 55.50 \\
\hline North Carolina $^{*}$ & 224 & -0.76 & 58.93 & Michigan & 428 & -0.60 & 58.67 \\
\hline Maine & 12 & -0.74 & 59.07 & Nevada & 188 & -0.39 & 60.97 \\
\hline Illinois ${ }^{*}$ & 352 & -0.64 & 59.99 & Mississippi & 298 & -0.28 & 62.20 \\
\hline Minnesota & 85 & -0.28 & 63.06 & South Carolina & 267 & -0.24 & 62.70 \\
\hline Delaware & 5 & -0.13 & 64.37 & Florida $^{* \circ}$ & 789 & -0.09 & 64.31 \\
\hline Oregon $^{\circ}$ & 150 & 0.06 & 66.00 & Idaho & 314 & 0.07 & 66.14 \\
\hline Mississippi & 134 & 0.11 & 66.45 & North Carolina & 351 & 0.19 & 67.48 \\
\hline Connecticut & 338 & 0.25 & 67.67 & West Virginia & 490 & 0.22 & 67.77 \\
\hline Alabama & 258 & 0.32 & 68.27 & Louisiana & 513 & 0.24 & 68.06 \\
\hline Hawaii & 309 & 0.36 & 68.59 & Wisconsin & 524 & 0.39 & 69.67 \\
\hline Ohio & 119 & 0.56 & 70.28 & Oregon & 359 & 0.44 & 70.23 \\
\hline Kentucky & 302 & 0.59 & 70.55 & New York & 337 & 0.69 & 73.07 \\
\hline Wisconsin $^{\dagger}$ & 15 & 0.78 & 72.20 & Utah & 340 & 0.72 & 73.38 \\
\hline Massachusetts $^{\circ}$ & 156 & 0.97 & 73.80 & North Dakota & 478 & 0.77 & 73.89 \\
\hline Pennsylvania & 153 & 1.05 & 74.51 & Colorado ${ }^{\circ}$ & 766 & 0.82 & 74.51 \\
\hline Maryland ${ }^{\circ}$ & 145 & 1.07 & 74.66 & Kentucky & 617 & 0.83 & 74.56 \\
\hline Virginia & 616 & 1.35 & 77.08 & Alabama & 587 & 0.89 & 75.32 \\
\hline New Jersey & 604 & 1.38 & 77.38 & Washington $^{\circ}$ & 754 & 0.94 & 75.81 \\
\hline New York & 1107 & 1.62 & 79.39 & Virginia & 943 & 0.97 & 76.21 \\
\hline Alaska $^{\dagger}$ & 166 & 1.97 & 82.49 & Minnesota & 874 & 1.03 & 76.79 \\
\hline Texas & 1081 & 2.24 & 84.73 & Oklahoma & 540 & 1.06 & 77.16 \\
\hline California & 1273 & 2.29 & 85.20 & Arkansas & 608 & 1.07 & 77.33 \\
\hline Florida & 2948 & 2.58 & 87.70 & Tennessee $^{\circ}$ & 745 & 1.10 & 77.60 \\
\hline Washington $^{\dagger}$ & 638 & 2.81 & 89.70 & Pennsylvania & 989 & 1.18 & 78.53 \\
\hline Michigan $^{\dagger}$ & 76 & 3.22 & 93.17 & Indiana & 889 & 1.30 & 79.83 \\
\hline \multirow[t]{13}{*}{ Louisiana } & 1895 & 4.01 & 100 & Georgia* $^{*}$ & 1,064 & 1.36 & 80.49 \\
\hline & & & & Montana $^{\circ}$ & 762 & 1.45 & 81.52 \\
\hline & & & & Arizona & 703 & 1.48 & 81.90 \\
\hline & & & & New Mexico & 595 & 1.48 & 81.90 \\
\hline & & & & Iowa & 985 & 1.55 & 82.68 \\
\hline & & & & Missouri & 1485 & 1.99 & 87.59 \\
\hline & & & & Texas $^{*}$ & 3249 & 2.04 & 88.10 \\
\hline & & & & Ohio & 1217 & 2.05 & 88.26 \\
\hline & & & & Kansas & 1494 & 2.07 & 88.46 \\
\hline & & & & Wyoming & 1220 & 2.14 & 89.23 \\
\hline & & & & California & 1377 & 2.26 & 90.55 \\
\hline & & & & Illinois & 2206 & 2.36 & 91.66 \\
\hline & & & & Nebraska & 3547 & 3.11 & 100 \\
\hline
\end{tabular}

Notes: Data on District of Columbia, Idaho, Kansas, Nebraska, and Puerto Rico by vessel and on Rhode Island by rail were not available after the data transformation; the state GDPs by vessel and rail were obtained from the United States Bureau of Economic Analysis, and measured in millions of dollars [47]; the GDP of Alaska in rail transport shows 0, which is explained by the value being much lower than one million; * means a state showing a relatively low AAQI compared with its high GDP level; † indicates a state holding a high rank in the AAQI compared with its low GDP level; ${ }^{\circ}$ means that a state showing a GDP level similar to other states, but it is differently ranked to others in the AAQI. 
Table 3. The first principal component and AAQI by state in the airline and truck transport sectors.

\begin{tabular}{|c|c|c|c|c|c|c|c|}
\hline \multicolumn{4}{|c|}{ Airline } & \multicolumn{4}{|c|}{ Truck } \\
\hline State & GDP & PC1 & AAQI & State & GDP & PC1 & AAQI \\
\hline Delaware & 18 & -5.05 & 0 & Idaho & 734 & -5.24 & 0 \\
\hline Virgin Islands & N/A & -4.48 & 6.00 & Rhode Island & 202 & -5.24 & 0.05 \\
\hline Vermont & 24 & -3.96 & 11.31 & District of Columbia & 18 & -4.45 & 8.63 \\
\hline Wyoming & 46 & -3.47 & 16.42 & Vermont & 221 & -4.28 & 10.46 \\
\hline Rhode Island & 79 & -3.44 & 16.68 & Delaware & 232 & -3.87 & 14.94 \\
\hline West Virginia & 16 & -2.96 & 21.67 & North Dakota ${ }^{*}$ & 560 & -2.51 & 29.72 \\
\hline North Dakota & 15 & -2.51 & 26.38 & Nevada ${ }^{*}$ & 683 & -2.34 & 31.62 \\
\hline South Dakota & 19 & -2.36 & 27.86 & South Dakota ${ }^{*}$ & 506 & -2.12 & 33.96 \\
\hline New Hampshire & 86 & -2.23 & 29.27 & Alaska & 285 & -2.07 & 34.51 \\
\hline Maine & 43 & -2.04 & 31.19 & New Hampshire & 289 & -1.92 & 36.13 \\
\hline Montana & 59 & -1.64 & 35.38 & Wyoming & 456 & -1.82 & 37.30 \\
\hline Iowa & 58 & -1.62 & 35.58 & Montana & 441 & -1.60 & 39.71 \\
\hline Connecticut ${ }^{*}$ & 270 & -1.57 & 36.09 & Maine & 490 & -1.56 & 40.11 \\
\hline Nebraska & 75 & -1.55 & 36.33 & Connecticut & 660 & -1.50 & 40.78 \\
\hline Kansas & 55 & -1.22 & 39.69 & West Virginia & 697 & -1.10 & 45.07 \\
\hline Idaho & 80 & -1.18 & 40.13 & Nebraska ${ }^{*}$ & 1,957 & -0.41 & 52.65 \\
\hline Puerto Rico & N/A & -1.17 & 40.23 & Utah & 1,551 & -0.28 & 54.01 \\
\hline New Mexico & 163 & -0.95 & 42.56 & Kansas & 1,508 & -0.18 & 55.17 \\
\hline Mississippi $^{\dagger}$ & 38 & -0.94 & 42.57 & New Mexico ${ }^{\dagger}$ & 700 & -0.15 & 55.41 \\
\hline Arkansas & 129 & -0.53 & 46.83 & Arkansas* & 2,549 & -0.06 & 56.41 \\
\hline South Carolina & 110 & -0.41 & 48.14 & Iowa $^{*}$ & 2,407 & -0.03 & 56.81 \\
\hline Utah & 782 & -0.28 & 49.48 & Oregon & 1,616 & 0.00 & 57.03 \\
\hline Oklahoma & 723 & -0.17 & 50.65 & Mississippi & 1,475 & 0.19 & 59.12 \\
\hline Oregon & 524 & 0.18 & 54.20 & Colorado & 1,634 & 0.22 & 59.53 \\
\hline Louisiana $^{\circ}$ & 370 & 0.21 & 54.57 & Maryland & 1400 & 0.33 & 60.65 \\
\hline Maryland & 622 & 0.27 & 55.11 & Massachusetts & 1462 & 0.48 & 62.30 \\
\hline Kentucky & 553 & 0.35 & 55.99 & South Carolina & 1584 & 0.49 & 62.45 \\
\hline Indiana & 493 & 0.45 & 57.04 & Louisiana & 1696 & 0.57 & 63.25 \\
\hline Missouri & 764 & 0.60 & 58.54 & Wisconsin $^{\circ}$ & 3767 & 0.66 & 64.22 \\
\hline Alabama $^{\dagger}$ & 95 & 0.66 & 59.24 & Alabama & 2125 & 0.75 & 65.30 \\
\hline Hawaii & 1037 & 0.79 & 60.52 & New Jersey ${ }^{\circ}$ & 3669 & 0.76 & 65.35 \\
\hline Nevada & 1102 & 0.81 & 60.75 & Oklahoma & 1736 & 0.94 & 67.27 \\
\hline Minnesota $^{*}$ & 2094 & 0.96 & 62.26 & Kentucky & 1812 & 1.02 & 68.14 \\
\hline New Jersey ${ }^{*}$ & 2390 & 1.00 & 62.70 & Virginia & 2420 & 1.18 & 69.93 \\
\hline Massachusetts $^{\dagger}$ & 865 & 1.00 & 62.73 & Minnesota & 2278 & 1.21 & 70.28 \\
\hline Virginia & 1784 & 1.44 & 67.29 & Washington $^{\circ}$ & 3767 & 1.45 & 72.82 \\
\hline Colorado & 1624 & 1.48 & 67.66 & New York & 3388 & 1.45 & 72.89 \\
\hline Michigan & 1683 & 1.54 & 68.32 & Arizona & 1834 & 1.59 & 74.35 \\
\hline Tennessee $^{\dagger}$ & 610 & 1.56 & 68.54 & Missouri $^{\circ}$ & 3646 & 1.61 & 74.58 \\
\hline Washington & 1489 & 1.60 & 68.88 & Indiana & 4490 & 1.65 & 75.10 \\
\hline Pennsylvania & 1355 & 1.61 & 69.05 & Pennsylvania & 5493 & 1.72 & 75.85 \\
\hline Ohio & 1494 & 1.62 & 69.19 & Tennessee & 4702 & 1.83 & 77.06 \\
\hline Alaska $^{\dagger}$ & 593 & 1.63 & 69.23 & North Carolina $^{\dagger \circ}$ & 3640 & 1.85 & 77.20 \\
\hline Arizona & 1888 & 2.04 & 73.50 & Ohio & 5990 & 2.22 & 81.22 \\
\hline North Carolina & 1309 & 2.08 & 73.89 & Michigan $^{\dagger}$ & 3453 & 2.38 & 83.04 \\
\hline Illinois & 4510 & 2.31 & 76.32 & Illinois & 6435 & 2.43 & 83.51 \\
\hline Wisconsin $^{\dagger \circ}$ & 403 & 2.35 & 76.74 & Georgia $^{\dagger}$ & 3979 & 2.79 & 87.42 \\
\hline New York & 4223 & 2.47 & 77.90 & Florida $^{\dagger}$ & 4003 & 3.10 & 90.83 \\
\hline Georgia & 4966 & 2.69 & 80.20 & Texas & 10,926 & 3.94 & 99.98 \\
\hline Florida & 4120 & 3.43 & 87.90 & California & 11,948 & 3.94 & 100 \\
\hline California & 6555 & 4.01 & 93.86 & & & & \\
\hline Texas & 7474 & 4.60 & 100 & & & & \\
\hline
\end{tabular}

Note: Data on District of Columbia by airline transport were not available after the data transformation; * means a state showing a relatively low AAQI compared with its high GDP level; † indicates a state holding a high rank in the AAQI compared with its low GDP level; ${ }^{\circ}$ means that a state showing a GDP level similar to other states, but it is differently ranked to others in the AAQI. 
Louisiana and Wisconsin, showing a similar GDP scale, are differently ranked in the AAQI, which also arises in rail transport with Missouri, New Jersey, North Carolina Washington, and Wisconsin.

\section{Conclusions}

Transportation is an essential part of the socioeconomic development of a nation, but it has been needed to accompany the undesirable output called air pollution even though advances in technology for modern transport have contributed to reducing air pollution emissions in comparison with past transport modes. On the other hand, the continuous increase in a clean air environment for public health and sustainable growth between current and future generations has had a positive effect on the transportation sector, corresponding to the growing tide of preserving and improving air quality over the past decades.

An easily understandable tool to measure the level of air pollution in the transportation sector by considering multiple air pollutants might raise awareness about clean air to the public, practitioners, state policy planners, and the government. In this study, an AAQI was developed to help prepare decision makers, which could rank a state according to different levels of multiple air pollutants. In the US empirical case, some states were shown as less polluted or more polluted in terms of the index, although their GDP levels for a transport mode were similar to each other. The authors would carefully guess that a possible hypothesis of these differences might be attributed to the degree of the use of eco-friendly transport, strictness of air quality standards, and differences in gasoline prices in their boundaries.

This study, however, has a limitation based on the use of the index developed. The index is only available for one sample, not multiple samples together, since each sample has its own different normalized eigenvectors of the sample covariance matrix according to PCA. Thus, the index value of the same state in different two samples by transport mode, e.g., in 2005 and 2008 if 2005 data were available cannot be theoretically compared with each other. However, one possible advantage of the AAQI developed here is that it can be applied to other numerous index development projects, not limited to the transportation sector.

\section{Acknowledgements}

This research was supported by Mountain-Plains Consortium, which is sponsored by the US Department of Transportation through its university Transportation Centers Program. The contents are sole responsibility of the authors. The authors would like to thank anonymous reviewers for their constructive comments.

\section{Author Contributions}

Jaesung Choi conceived of the research and wrote the paper. Ju Dong Park and Yong Shin Park analyzed the data and performed the multivariate analysis. All authors discussed and commented the results and implications.

\section{Conflicts of Interests}

The authors declare no conflict of interest.

\section{References}

[1] Kampa, M. and Castanas, E. (2008) Human Health Effects of Air Pollution. Environmental Pollution, 151, $362-367$. http://dx.doi.org/10.1016/j.envpol.2007.06.012

[2] Chang, T. and Gross, T. (2014) Particulate Pollution and the Productivity of Pear Packers. http://www.nber.org/papers/w19944.pdf

[3] Zivin, J.S.G. and Neidell, M.J. (2014) The Impact of Pollution on Worker Productivity. http://www.nber.org/papers/w17004.pdf

[4] Greenstone, M. and Looney, A. (2011) We Are What We Breathe: The Impacts of Air Pollution on Employment and Productivity. http://www.brookings.edu/blogs/jobs/posts/2011/05/06-jobs-greenstone-looney

[5] Wyon, D. (2014) The Effects of Indoor Air Quality on Performance and Productivity. http://www.ncbi.nlm.nih.gov/pubmed/15330777

[6] Kosonen, R. and Tan, F. (2004) The Effect of Perceived Indoor Air Quality on Productivity Loss. Energy and Buildings, 36, 981-986. http://dx.doi.org/10.1016/j.enbuild.2004.06.005 
[7] Wargocki, P., Wyon, D.P. and Fanger, P.O. (2000) Productivity Is Affected by the Air Quality in Offices. Proceedings of Healthy Buildings, 1, 635-640.

[8] Peck, W. and Harmelink, M. (2014) Transportation Air Pollution. http://trid.trb.org/view.aspx?id=114537

[9] Gorham, R. (2014) Air Pollution from Ground Transportation. http://www.un.org/esa/gite/csd/gorham.pdf

[10] Thom, G.C. and Ott, W.R. (1975) Air Pollution Indices: A Compendium and Assessment of Indices Used in the U.S. and Canada. Ann Arbor Science Publishers, Ann Arbor.

[11] The Federal Interagency Task Force (1976) A Recommended Air Pollution Index. United States Government Printing Office, Washington DC.

[12] Hämekoski, K. (1998) The Use of a Simple Air Quality Index in the Helsinki Area, Finland. Environmental Management, 22, 517-520. http://dx.doi.org/10.1007/s002679900124

[13] The United States Environmental Protection Agency. Air Quality Index Reporting: Final Rule. http://www.epa.gov/ttn/oarpg/t1/fr_notices/airqual.pdf

[14] Trozzi, C., Vaccaro, R. and Crocetti, S. (1999) Air Quality Index and Its Use in Italy’s Management Plans. Science of the Total Environment, 235, 387-389. http://dx.doi.org/10.1016/S0048-9697(99)00242-9

[15] Sharma, M., Maheshwari, M., Sengupta, B. and Shukla, B. (2003) Design of a Website for Dissemination of Air Quality Index in India. Environmental Modelling \& Software, 18, 405-411. http://dx.doi.org/10.1016/S1364-8152(03)00003-3

[16] Sharma, M., Pandey, R., Maheshwari, M., Sengupta, B., Shukla, B., Gupta, N. and Johri, S. ( 2003) Interpretation of Air Quality Data Using an Air Quality Index for the City of Kanpur, India. Journal of Environmental Engineering and Science, 2, 435-462.

[17] Murena, F. (2004) Measuring Air Quality over Large Urban Areas: Development and Application of an Air Pollution Index at the Urban Area of Naples. Atmospheric Environment, 38, 6195-6202. http://dx.doi.org/10.1016/j.atmosenv.2004.07.023

[18] Nagendra, S.S., Venugopal, K. and Jones, S.L. (2007) Assessment of Air Quality near Traffic Intersections in Bangalore City Using Air Quality Indices. Transportation Research Part D: Transport and Environment, 12, 167-176. http://dx.doi.org/10.1016/j.trd.2007.01.005

[19] Wen, X.-J., Balluz, L. and Mokdad, A. (2009) Association between Media Alerts of Air Quality Index and Change of Outdoor Activity among Adult Asthma in Six States, BRFSS, 2005. Journal of Community Health, 34, 40-46. http://dx.doi.org/10.1007/s10900-008-9126-4

[20] Eder, B., Kang, D.W., Trivikrama, R.S., Rohit, M., Shaocai, Y., Tanya, O., Ken, S., Richard, W., Scott, J., Paula, D., Jeff, M. and George, B. (2010) Using National Air Quality Forecast Guidance to Develop Local Air Quality Index Forecasts. Bulletin of the American Meteorological Society, 91, 313-326.

[21] Swamee, P.K. and Tyagi, A. (1999) Formation of an Air Pollution Index. Journal of the Air \& Waste Management Association, 49, 88-91. http://dx.doi.org/10.1080/10473289.1999.10463776

[22] Cheng, W.-L., Kuo, Y.-C., Lin, P.-L., Chang, K.-H., Chen, Y.-S., Lin, T.-M. and Huang, R. (2004) Revised Air Quality Index Derived from an Entropy Function. Atmospheric Environment, 38, 383-391. http://dx.doi.org/10.1016/j.atmosenv.2003.10.006

[23] Cheng, W.-L., Chen, Y.-S., Zhang, J., Lyons, T., Pai, J.-L. and Chang, S.-H. (2007) Comparison of the Revised Air Quality Index with the PSI and AQI Indices. Science of the Total Environment, 382, 191-198. http://dx.doi.org/10.1016/j.scitotenv.2007.04.036

[24] Kyrkilis, G., Chaloulakou, A. and Kassomenos, P.A. (2007) Development of an Aggregate Air Quality Index for an Urban Mediterranean Agglomeration: Relation to Potential Health Effects. Environment International, 33, 670-676. http://dx.doi.org/10.1016/j.envint.2007.01.010

[25] Bishoi, B., Prakash, A. and Jain, V. (2009) A Comparative Study of Air Quality Index Based on Factor Analysis and US-EPA Methods for an Urban Environment. Aerosol and Air Quality Research, 9, 1-17.

[26] Longhurst, J. (2005) 1 to 100: Creating an Air Quality Index in Pittsburgh. Environmental Monitoring and Assessment, 106, 27-42.

[27] Stieb, D.M., Doiron, M.S., Blagden, P. and Burnett, R.T. (2005) Estimating the Public Health Burden Attributable to Air Pollution: An Illustration Using the Development of an Alternative Air Quality Index. Journal of Toxicology and Environmental Health, Part A: Current Issues, 68, 1275-1288. http://dx.doi.org/10.1080/15287390590936120

[28] Stieb, D.M., Burnett, R.T., Marc, S.-D., Brion, O., Shin, H.H. and Economou, V. (2008) A New Multipollutant, No-Threshold Air Quality Health Index Based on Short-Term Associations Observed in Daily Time-Series Analyses. Journal of the Air \& Waste Management Association, 58, 435-450. 
[29] Mohan, M. and Kandya, A. (2007) An Analysis of the Annual and Seasonal Trends of Air Quality Index of Delhi. Environmental Monitoring and Assessment, 131, 267-277. http://dx.doi.org/10.1007/s10661-006-9474-4

[30] Mayera, H., Holsta, J., Schindlera, D. and Ahrensb, D. (2008) Evolution of the Air Pollution in SW Germany Evaluated by the Long-Term Air Quality Index LAQx. Atmospheric Environment, 42, 5071-5078. http://dx.doi.org/10.1016/j.atmosenv.2008.02.020

[31] Sowlat, M.H., Gharibi, H., Yunesian, M., Mahmoudi, M. and Lotfi, S. (2011) A Novel, Fuzzy-Based Air Quality Index (FAQI) for Air Quality Assessment. Atmospheric Environment, 45, 2050-2059. http://dx.doi.org/10.1016/j.atmosenv.2011.01.060

[32] Vyas, S. and Kumaranayake, L. (2006) Constructing Socio-Economic Status Indices: How to Use Principal Components Analysis. Health Policy Plan, 21, 459-468. http://dx.doi.org/10.1093/heapol/czl029

[33] Soler-Rovira, J. and Soler-Rovira, P. (2008) Assessment of Aggregated Indicators of Sustainability Using PCA: The Case of Apple Trade in Spain. Proceedings of the 6th International Conference on LCA in the Agri-Food Sector, Zurich, 12-14 November 2008, 133-143.

[34] Ali Hatem, M.M. (2009) Development of Arab Water Sustainability Index Using Principal Component Analysis. Proceedings of the 13th International Water Technology Conference, Hurghada, 1563-1578.

[35] Li, T., Zhang, H., Yuan, C. and Liu, Z. (2012) A PCA-Based Method for Construction of Composite Sustainability Indicators. The International Journal of Life Cycle Assessment, 17, 593-603. http://dx.doi.org/10.1007/s11367-012-0394-y

[36] Hosseini, H.M. and Kaneko, S. (2011) Dynamic Sustainability Assessment of Countries at the Macro Level: A Principal Component Analysis. Ecological Indicators, 11, 811-823. http://dx.doi.org/10.1016/j.ecolind.2010.10.007

[37] Park, Y.S., Egilmez, G. and Kucukvar, M. (2015) A Novel Life Cycle-Based Principal Component Analysis Framework for Eco-Efficiency Analysis: Case of the U.S. Manufacturing and Transportation Nexus. Journal of Cleaner Production, in Press.

[38] Tripping, M.E. and Bishop, C.M. (2002) Probabilistic Principal Component Analysis. Journal of the Royal Statistical Society: Series B (Statistical Methodology), 61, 611-622. http://dx.doi.org/10.1111/1467-9868.00196

[39] Nagendra, S.S. and Khare, M. (2003) Principal Component Analysis of Urban Traffic Characteristics and Meteorological Data. Transportation Research Part D: Transport and Environment, 8, 285-297. http://dx.doi.org/10.1016/S1361-9209(03)00006-3

[40] Rencher, A.C. and Christensen, W.F. (2012) Methods of Multivariate Analysis. 3rd Edition, John Wiley \& Sons, Inc., Hoboken. http://dx.doi.org/10.1002/9781118391686

[41] Han, B., Bai, Z., Ji, H., Guo, G., Wang, F., Shi, G. and Li, X. (2009) Chemical Characterizations of PM10 Fraction of Paved Road Dust in Anshan, China. Transportation Research Part D: Transport and Environment, 14, 599-603. http://dx.doi.org/10.1016/j.trd.2009.07.010

[42] The United States Environmental Protection Agency (2014) Air Quality Trends. http://www.epa.gov/airtrends/aqtrends.html

[43] Choi, J., Roberts, D.C. and Lee, E. (2014) Forecast of CO2 Emissions from the U.S. Transportation Sector: Estimation from a Double Exponential Smoothing Model. Journal of the Transportation Research Forum, 53, 63-82.

[44] The United States Environmental Protection Agency (2014) Air Pollution and the Clean Air Act. http://www.epa.gov/air/caa/

[45] Mendenhall, W. and Sincich, T. (2011) A Second Course in Statistics: Regression Analysis. 7th Edition, Prentice Hall, Upper Saddle River, 797.

[46] Ramzan, S., Zahid, F.M. and Ramzan, S. (2013) Evaluating Multivariate Normality: A Graphical Approach. MiddleEast Journal of Scientific Research, 13, 254-263.

[47] The United States Bureau of Economic Analysis (2014) Industry Data. http://www.bea.gov/iTable/index_industry_gdpIndy.cfm

[48] The United States Environmental Protection Agency (2014) Emission Inventories. http://www.epa.gov/ttn/chief/eiinformation.html 


\begin{tabular}{|c|c|c|c|c|c|}
\hline Author(s) & Year & Study area & Pollutants measured & Methodology & Objective(s) \\
\hline Thom and Ott & 1975 & $\begin{array}{l}\text { US and } \\
\text { Canada }\end{array}$ & $\begin{array}{l}\mathrm{CO}, \mathrm{NO}_{\mathrm{X}} \text {, Oxidants, } \\
\mathrm{PM} \text {, and } \mathrm{SO}_{2}\end{array}$ & Standardized AQI & Developing a uniform AQI \\
\hline $\begin{array}{l}\text { Federal Interagency } \\
\text { Task Force }\end{array}$ & 1976 & US & $\begin{array}{l}\mathrm{CO}, \mathrm{NO}_{\mathrm{x}}, \mathrm{O}_{3}, \mathrm{SO}_{2} \\
\text { and } \mathrm{TSP}^{7}\end{array}$ & PSI & $\begin{array}{l}\text { Developing an AQI to report daily air } \\
\text { quality by state }\end{array}$ \\
\hline Hämekoski & 1998 & Finland & $\begin{array}{l}\mathrm{CO}, \mathrm{NO}_{\mathrm{X}}, \mathrm{O}_{3}, \mathrm{PM} \\
\text { and } \mathrm{SO}_{2}\end{array}$ & PSI & Applying a PSI in the Helsinki area, Finland \\
\hline $\begin{array}{l}\text { Swamee and } \\
\text { Tyagi }\end{array}$ & 1999 & India & $\begin{array}{l}\mathrm{CO}, \text { Haze, } \mathrm{NO}_{\mathrm{x}}, \mathrm{O}_{3} \text {, } \\
\mathrm{SO}_{2} \text {, and TSP }\end{array}$ & $\begin{array}{l}\text { Ambiguity- and } \\
\text { eclipsicity-free function }\end{array}$ & $\begin{array}{l}\text { Developing an overall AQI from the aggregation } \\
\text { of air pollution sub-indices }\end{array}$ \\
\hline Trozzi et al. & 1999 & Italy & $\begin{array}{l}\mathrm{CO}, \mathrm{NO}_{\mathrm{X}}, \mathrm{O}_{3}, \mathrm{PM} \\
\text { and } \mathrm{SO}_{2}\end{array}$ & AQI & $\begin{array}{l}\text { Applying an AQI developed by } \\
\text { the USEPA for Italy }\end{array}$ \\
\hline USEPA & 1999 & US & $\begin{array}{l}\mathrm{CO}, \mathrm{NO}_{\mathrm{x}}, \mathrm{O}_{3}, \mathrm{PM} \\
\text { and } \mathrm{SO}_{2}\end{array}$ & AQI & $\begin{array}{l}\text { Revisions from the PSI to provide } \\
\text { additional air quality information }\end{array}$ \\
\hline Sharma et al. & $2003 \mathrm{~A}$ & India & $\begin{array}{l}\mathrm{CO}, \mathrm{NO}_{\mathrm{x}}, \mathrm{O}_{3}, \mathrm{PM} \text {, } \\
\text { and } \mathrm{SO}_{2} \text {, and } \mathrm{SPM}^{8}\end{array}$ & AQI & $\begin{array}{l}\text { Describing the design of a website } \\
\text { for the dissemination of AQIs }\end{array}$ \\
\hline Sharma et al. & 2003B & India & $\begin{array}{l}\mathrm{CO}, \mathrm{NO}_{\mathrm{x}}, \mathrm{O}_{3}, \mathrm{PM} \text {, } \\
\text { and } \mathrm{SO}_{2} \text {, and SPM }\end{array}$ & AQI & $\begin{array}{l}\text { Applying an AQI developed by the } \\
\text { USEPA for the City of Kanpur, India }\end{array}$ \\
\hline Cheng et al. & 2004 & Taiwan & $\begin{array}{l}\mathrm{CO}, \mathrm{NO}_{\mathrm{X}}, \mathrm{O}_{3}, \mathrm{PM} \\
\text { and } \mathrm{SO}_{2}\end{array}$ & Revised AQI (RAQI) & $\begin{array}{l}\text { Developing an RAQI as combining } \\
\text { a PSI with an entropy function }\end{array}$ \\
\hline Murena & 2004 & Italy & $\begin{array}{l}\mathrm{CO}, \mathrm{NO}_{\mathrm{X}}, \mathrm{O}_{3}, \mathrm{PM} \text {, } \\
\text { and } \mathrm{SO}_{2}\end{array}$ & AQI & $\begin{array}{l}\text { Implementing an AQI in the urban area of } \\
\text { Naples to measure the level of air pollution }\end{array}$ \\
\hline Longhurst & 2005 & US & $\mathrm{SO}_{2}$ and particulates & Simple formula ${ }^{9}$ & $\begin{array}{l}\text { Presenting the case study of an AQI } \\
\text { in Pittsburgh, Pennsylvania }\end{array}$ \\
\hline Stieb et al. & 2005 & Canada & $\begin{array}{l}\mathrm{CO}, \mathrm{NO}_{\mathrm{X}}, \mathrm{O}_{3}, \mathrm{PM} \\
\text { and } \mathrm{SO}_{2}\end{array}$ & $\begin{array}{l}\text { Time series regression } \\
\text { on five air pollutants } \\
\text { on mortality }\end{array}$ & $\begin{array}{l}\text { Developing an alternative AQI to } \\
\text { illustrate the public health burden } \\
\text { attributable to air pollution }\end{array}$ \\
\hline Cheng et al. & 2007 & Taiwan & $\begin{array}{l}\mathrm{CO}, \mathrm{NO}_{\mathrm{x}}, \mathrm{O}_{3}, \mathrm{PM} \text {, } \\
\text { and } \mathrm{SO}_{2}\end{array}$ & RAQI & $\begin{array}{l}\text { Comparisons between an RAQI and a PSI or AQI } \\
\text { for evaluating the feasibility and effectiveness of } \\
\text { several air pollution conditions }\end{array}$ \\
\hline Kyrkilis et al. & 2007 & Greece & $\begin{array}{l}\mathrm{CO}, \mathrm{NO}_{\mathrm{x}}, \mathrm{O}_{3}, \mathrm{PM} \text {, } \\
\text { and } \mathrm{SO}_{2}\end{array}$ & AAQI & $\begin{array}{l}\text { Calculating potential health effects } \\
\text { considering five criteria pollutants }\end{array}$ \\
\hline $\begin{array}{l}\text { Mohan and } \\
\text { Kandya }\end{array}$ & 2007 & India & $\begin{array}{l}\mathrm{CO}, \mathrm{NO}_{\mathrm{X}}, \mathrm{O}_{3}, \mathrm{PM} \text {, } \\
\text { and } \mathrm{SO}_{2}\end{array}$ & AQI & $\begin{array}{l}\text { Measuring the annual and seasonal } \\
\text { variations of AQI from } 1996 \text { to } 2004\end{array}$ \\
\hline Nagendra et al. & 2007 & India & $\begin{array}{l}\text { Ammonia, CO, lead, } \\
\mathrm{NO}_{\mathrm{X}}, \mathrm{O}_{3}, \mathrm{SO}_{2}, \mathrm{SPM} \text {, } \\
\text { and } \mathrm{RPM}^{10}\end{array}$ & AQI & $\begin{array}{l}\text { Assessing the level of ambient air quality } \\
\text { at traffic intersections in Bangalore, India } \\
\text { using an AQI developed by the USEPA }\end{array}$ \\
\hline Mayer et al. & 2008 & Germany & $\begin{array}{l}\text { Benzene, } \mathrm{NO}_{\mathrm{x}}, \mathrm{PM} \text {, } \\
\text { and } \mathrm{SO}_{2}\end{array}$ & Long-term AQI (LAQI) & $\begin{array}{l}\text { Analyzing the effect of the integral } \\
\text { long-term air pollution for 1985-2005 }\end{array}$ \\
\hline Stieb et al. & 2008 & Canada & $\begin{array}{l}\mathrm{CO}, \mathrm{NO}_{\mathrm{x}}, \mathrm{O}_{3}, \mathrm{PM} \text {, } \\
\text { and } \mathrm{SO}_{2}\end{array}$ & $\begin{array}{l}\text { Air quality health index } \\
\text { (AQHI) using time series } \\
\text { regression on five air } \\
\text { pollutants on mortality }\end{array}$ & $\begin{array}{l}\text { Developing an AQHI and applying it in } \\
\text { multiple Canadian cities }\end{array}$ \\
\hline Bishoi and Jain & 2009 & India & $\begin{array}{l}\mathrm{CO}, \mathrm{NO}_{\mathrm{X}}, \mathrm{O}_{3}, \mathrm{PM} \text {, } \\
\text { and } \mathrm{SO}_{2}\end{array}$ & $\begin{array}{l}\text { New AQI (NAQI) with } \\
\text { factor analysis }\end{array}$ & $\begin{array}{l}\text { Comparing an NAQI to an AQI developed } \\
\text { by the USEPA }\end{array}$ \\
\hline Wen et al. & 2009 & US & $\begin{array}{l}\mathrm{CO}, \mathrm{NO}_{\mathrm{x}}, \mathrm{O}_{3}, \mathrm{PM} \text {, } \\
\text { and } \mathrm{SO}_{2}\end{array}$ & AQI & $\begin{array}{l}\text { Studying the relationship between media } \\
\text { alerts of AQI and level of outdoor activity }\end{array}$ \\
\hline Eder et al. & 2010 & US & $\begin{array}{l}\mathrm{CO}, \mathrm{NO}_{\mathrm{X}}, \mathrm{O}_{3}, \mathrm{PM} \\
\text { and } \mathrm{SO}_{2}\end{array}$ & AQI & $\begin{array}{l}\text { Developing local AQI forecasts using an } \\
\text { AQI developed by the USEPA }\end{array}$ \\
\hline Sowlat et al. & 2011 & Iran & $\begin{array}{l}\mathrm{CO}, \mathrm{NO}_{\mathrm{x}}, \mathrm{O}_{3}, \mathrm{PM}, \mathrm{SO}_{2} \text {, } \\
\text { benzene, toluene, } \\
\text { ethyl-benzene, xylene, } \\
\text { and 1, 3-butadiene }\end{array}$ & Fuzzy-based AQI (FAQI) & $\begin{array}{l}\text { Developing a FAQI based on the } \\
\text { computational method of artificial } \\
\text { intelligence and assessing the performance } \\
\text { of the index as a case study of Iran }\end{array}$ \\
\hline
\end{tabular}

\footnotetext{
${ }^{7}$ TSP stands for total suspended particulates.

${ }^{8} \mathrm{SPM}$ stands for suspended particulate matter.

${ }^{9}$ Simple formula is as follows: $50\left(\left(\mathrm{SO}_{2} / 0.14\right)+(\mathrm{COH} / 1.73)\right)$, where $\mathrm{SO}_{2}$ represents its measurement and $\mathrm{COH}$ means the coefficient of haze; the denominators in the formula are based on National Ambient Air Quality Standards [26].

${ }^{10} \mathrm{RPM}$ stands for Respirable Particulate Matter.
} 